The Expense of Spirit 



\section{The Expense of Spirit LOVE AND SEXUALITY IN ENGLISH RENAISSANCE DRAMA}

\section{Mary Beth Rose}

Cornell University Press ITHACA AND LONDON 
Open access edition funded by the National Endowment for the Humanities/ Andrew W. Mellon Foundation Humanities Open Book Program.

Cornell University Press gratefully acknowledges a grant from the Andrew W. Mellon Foundation that aided in bringing this book to publication.

\section{Copyright (C) 1988 by Cornell University}

All rights reserved. Except for brief quotations in a review, this book, or parts thereof, must not be reproduced in any form without permission in writing from the publisher. For information, address Cornell University Press, Sage House, 512 East State Street, Ithaca, New York 14850, or visit our website at cornellpress.cornell.edu.

First published 1988 by Cornell University Press

First printing, Cornell Paperbacks, 1991

Library of Congress Cataloging-in-Publication Data

Rose, Mary Beth.

The expense of spirit : love and sexuality in English renaissance drama. Includes index.

1. English drama - Early modern and Elizabethan, 1500-1600-History and criticism. 2. English drama-17th century-History and criticism. 3. Love in literature. 4. Sex in literature. 5. Women and literature-England-History. 6. Women-England-History. 7. Literary form. I. Title.

PR658.L63R6 1988 822'.3'09354 88-47742

ISBN-13: 978-0-8014-2189-1 (cloth) — ISBN-13: 978-0-8014-9695-0 (pbk.)

The text of this book is licensed under a Creative Commons Attribution-NonCommercial-NoDerivatives 4.0 International License: https://creativecommons.org/licenses/by-nc-nd/4.0/ 
For Larry, for my mother, Roberta Block Rose, and in memory of my father, Lincoln Rose 
